\title{
Spinal anesthesia for elective cesarean section is associated with shorter hospital stay compared to general anesthesia
}

\section{Elektif sezaryen ameliyatlarında spinal anestezi genel anesteziye kuyasla bastanede kalış süresini kısaltmaktadır}

\author{
Fadıl HAVAS, Mukadder ORHAN SUNGUR, YIImaz YENIGÜN, \\ Meltem KARADENIZ, Miray KILIÇ, Tülay ÖZKAN SEYHAN
}

\begin{abstract}
Summary
Objectives: This prospective study aims to compare maternal and neonatal effects of spinal and general anesthesia for elective cesarean section.

Methods: Term parturients receiving routine spinal (Group SA, $n=95$ ) or general (Group GA, $n=93$ ) anesthesia and standard postoperative analgesia for elective cesarean section were included in this study. Operation time, incision-hysterotomy $\left(\mathrm{T}_{\mathrm{S}-\mathrm{H}}\right)$ and hysterotomy-umbilical cord clamping $\left(\mathrm{T}_{\mathrm{H}-\mathrm{U}}\right)$ intervals, oxytocine requirement, intraoperative fluids, ephedrine requirement, incidence of hypotension, time to first analgesic requirement $\left(\mathrm{T}_{\text {analg }}\right)$, pethidine consumption, adverse events, time to first breastfeeding, oral food intake $\left(T_{\mathrm{OI}}\right)$, flatulence $\left(\mathrm{T}_{\mathrm{F}}\right)$, defecation $\left(\mathrm{T}_{\mathrm{D}}\right)$, mobilization, and postoperative hospital stay were compared between the groups. Newborn Apgar scores, umbilical venous blood gas analysis, incidence of hypoglycemia, nutritional support, phototherapy and ventilatory support were also analyzed.

Results: Spinal anesthesia was associated with longer $T_{\mathrm{S}-\mathrm{H}}$ and $\mathrm{T}_{\mathrm{H}-\mathrm{U}}$ durations, lower oxytocine requirements, higher incidence of hypotension, increased ephedrine and fluid consumption, and delayed $\mathrm{T}_{\text {analg }}$. Furthermore, $\mathrm{T}_{\mathrm{OI}}, \mathrm{T}_{\mathrm{F}}, \mathrm{T}_{\mathrm{D}}$ and postoperative hospital stay was shorter in patients given spinal anesthesia when compared with patients given general anesthesia ( $48 \mathrm{~h}$ vs. $52 \mathrm{~h}$, respectively; $\mathrm{p}<0.01$ ). No difference in postoperative analgesic consumption and neonatal outcomes, except $1^{\text {st }}$ min Apgar scores and umbilical blood gas analysis, was detected.

Conclusion: Spinal anesthesia, when compared to general anesthesia shortens postoperative hospital stay with early return of gastrointestinal functions in elective cesarean section.
\end{abstract}

Key words: Cesarean section; gastrointestinal motility; general anesthesia; hospital stay; spinal anesthesia.

Özet

Amaç: Bu prospektif çalışmada elektif sezaryen ameliyatlarında spinal ve genel anestezinin anne ve yenidoğan üzerine etkilerinin kiyaslanması amaçlanmıştır.

Gereç ve Yöntem: Elektif sezaryen ameliyatı için rutin spinal (Grup SA, $n=95)$ veya genel anestezi (Grup GA, $n=93$ ) ile standart postoperatif analjezi uygulanan miyadında gebeler çalı̧maya alınmıştır. Ameliyat süresi, cilt insizyonu-bisterotomi $\left(T_{S-H}\right)$ ve histerotomi-umbilikal kordona klemp konması arası geçen süre $\left(T_{H-U}\right)$, oksitosin gereksinimi, intraoperatif sivi, efedrin gereksinimi, hipotansiyon gelişen hasta sayısı, ilk analjezik gereksinimine dek geçen süre $\left(T_{\text {analg }}\right)$, petidin tüketimi, yan etkiler, ilk emzirme, annenin oral gıda alımı $\left(T_{O I}\right)$, gaz çıkarma $\left(T_{F}\right)$, defekasyon $\left(T_{D}\right)$, mobilizasyon ve hastanede kalıs süresi gruplar arasında kıyaslanmıştır. Yenidoğanın Apgar skorları, umblikal venöz kan gazı, hastanede kaldığı süre boyunca bipoglisemi gelişimi, ek gıda, fototerapi ve solunum desteği gereksinimi karşılaştırılmıştır.

Bulgular: Spinal anestezide genel anesteziye oranla daha uzun $T_{S \cdot H^{\prime}} T_{H \cdot U}$ süreleri gözlenmiş, oksitosin gereksinimi azalmış, hipotansiyon insidansı, efedrin ve sıvı gereksiniminde artış saptanmış, $T_{\text {analg }}$ süresi uzamıştır. Ayrıca spinal anestezi sonrası $T_{O I}, T_{F}, T_{D}$ ve bastanede kalıs süresinin genel anesteziye oranla (sırasıyla 48 ve 52 saat, $p<0.01$ ) kısaldı̆̆ı saptanmıştır. Postoperatif analjezik tüketimi ve 1. dak Apgar skoru ile umbilikal kan gazı sonuçları dışında neonatal veriler açısından gruplar arasında fark bulunmamıştır.

Sonuç: Elektif sezaryen ameliyatlarında spinal anestezi genel anesteziye oranla daba bizl gastrointestinal derlenmeyi sağlamakta, hastanede kalı̧̧ süresini kısaltmaktadır.

Anahtar sözcükler: Sezaryen; gastrointestinal motilite; genel anestezi; hastanede kalış süresi; spinal anestezi.

Department of Anesthesiology, Istanbul University Istanbul Faculty of Medicine, Istanbul, Turkey istanbul Üniversitesi Istanbul Tıp Fakültesi, Anesteziyoloji Anabilim Dalı, İstanbul

Submitted (Başvuru tarihi) 16.01.2012 Accepted after revision (Düzeltme sonrası kabul tarihi) 11.04.2012

Correspondence (İletişim): Tülay Özkan Seyhan, M.D. İstanbul Üniversitesi İstanbul Tıp Fakültesi, Anesteziyoloji Anabilim Dalı, Çapa Klinikleri, 34093 İstanbul, Turkey.

Tel: +90 - 212 - 6318767 e-mail (e-posta): tulay2000@gmail.com 


\section{Introduction}

Neuraxial anesthesia is the preferred method in cesarean section as general anesthesia is associated with airway related adverse outcome, aspiration risk, intraoperative awareness and increased uterine atony leading to higher blood loss. ${ }^{[1]}$ General anesthesia is performed in cases of contraindication to neuraxial anesthesia, failure of neuraxial technique or patient request for elective cesarean section. [2] The favorable effects of neuraxial anesthesia on newborns has been demonstrated previously, ${ }^{[3,4]}$ yet there is limited evidence on the effect of anesthetic techniques for maternal outcomes such as length of postoperative hospital stay and return of gastrointestinal functions. ${ }^{[5]}$ This prospective study aims to compare the effects of spinal and general anesthesia on mother and neonate with length of hospital stay as primary outcome.

\section{Materials and Methods}

Following approval by the Institutional Clinical Research Ethics Committee and patients' informed consents, parturients undergoing elective cesarean section were included in this prospective study. Patients with gestation weeks $<36$ weeks, body mass in$\operatorname{dex}(\mathrm{BMI}) \geq 35 \mathrm{~kg} / \mathrm{m}^{2}$, ASA status $\geq$ III, preeclampsia, multiple pregnancy, Rhesus immunization, fetal compromise or anomaly and patients in need of emergency operation have not been enrolled.

Following preoperative anesthetic evaluation, patients were divided into two groups: spinal anesthesia (Group SA) and general anesthesia (Group GA). Noninvasive blood pressure, ECG and $\mathrm{SpO}_{2}$ were monitored and data were recorded prior to anesthesia induction and thereafter at $3 \mathrm{~min}$ intervals. All patients received $500 \mathrm{~mL}$ of lactated Ringer solution. Spinal anesthesia was performed in sitting position at L3-4 or L4-5 interspinous levels with 25G spinal needle (Quincke tip, Braun). Fentanyl $20 \mu \mathrm{g}$ combined with hyperbaric bupivacaine 8-10 $\mathrm{mg}$ were injected intrathecally to achieve a sensorial block at T4 level. General anesthesia was induced after preoxygenation with thiopental $5-7 \mathrm{mg} / \mathrm{kg}$, succinylcholine $1 \mathrm{mg} / \mathrm{kg}$. Following orotracheal intubation, patients were ventilated to achieve an $\mathrm{ETCO}_{2}$ of $32-35 \mathrm{mmHg}$. Anesthesia was maintained with $1.5 \%$ sevoflurane in oxygen. After delivery, fentanyl
$2 \mu \mathrm{g} / \mathrm{kg}$, midazolam $0.03 \mathrm{mg} / \mathrm{kg}$ and rocuronium $0.15 \mathrm{mg} / \mathrm{kg}$ were administered intravenously and sevoflurane was continued at $1 \%$ in $50 \%$ oxygen$50 \% \mathrm{~N}_{2} \mathrm{O}$ mixture. Anesthesia was discontinued at the end of surgery and patients were extubated with reversal of muscle relaxation.

All patients were positioned supine with left lateral uterine displacement during operation. Following delivery, they received iv ampicillin/sulbactam $1 \mathrm{gr}$, ranitidine $20 \mathrm{mg}$ and oxytocine $25 \mathrm{IU}$ infused over 30 minutes. If uterine tone assessed by surgical palpation was inadequate, supplemental oxytocine was utilized. In case of hypotension, defined as decrease in systolic blood pressure (SAP) of $\geq 30 \%$ of baseline or a value of SAP $<100 \mathrm{mmHg}$, rate of iv fluid infusion was increased. If hypotension persisted in the next consecutive measurement, an ephedrine bolus of $5 \mathrm{mg}$ was administered. Heart rate $<60 \mathrm{bpm}$ was planned to be treated with atropine.

Postoperative pain was evaluated using verbal rating scale (VRS; $0=$ no pain...10=worst possible pain). Analgesia was started when patients complained of a pain score $\geq 4$ with $10-15 \mathrm{mg}$ iv pethidine bolus at 7 min intervals at postoperative care unit (PACU). Maintenance analgesia in the ward was achieved with im diclofenac $75 \mathrm{mg}$ bi-daily and iv patient controlled analgesia (PCA) with pethidine. PCA pump was programmed to deliver pethidine 0.05 $\mathrm{mg} / \mathrm{kg} / \mathrm{h}$ basal infusion, $0.1 \mathrm{mg} / \mathrm{kg}$ PCA bolus with 7 min lock-out. Patients were advised preoperatively for free oral intake and breast feeding following surgery as soon as possible.

Maternal age, BMI, gestation week, operation duration, time from skin incision to hysterotomy $\left(\mathrm{T}_{S-\mathrm{H}}\right)$ and hysterotomy to umbilical cord clamping $\left(\mathrm{T}_{\mathrm{H}-\mathrm{U}}\right)$, oxytocine consumption were documented. Intraoperative fluid, number of patients with ephedrine requirement, ephedrine consumption and number of patients with intraoperative hypotension were recorded. Time to first analgesic requirement $\left(\mathrm{T}_{\text {analg }}\right)$, pethidine consumption at PACU, pethidine-PCA consumption at ward and VRS scores as well as side effects like postoperative nausea, vomiting (PONV), pruritus and postdural puncture headache were also documented. Time to first breast feeding $\left(\mathrm{T}_{\mathrm{BF}}\right)$, oral intake $\left(\mathrm{T}_{\mathrm{OI}}\right)$, flatulence $\left(\mathrm{T}_{\mathrm{F}}\right)$, defecation $\left(\mathrm{T}_{\mathrm{D}}\right)$, mo- 


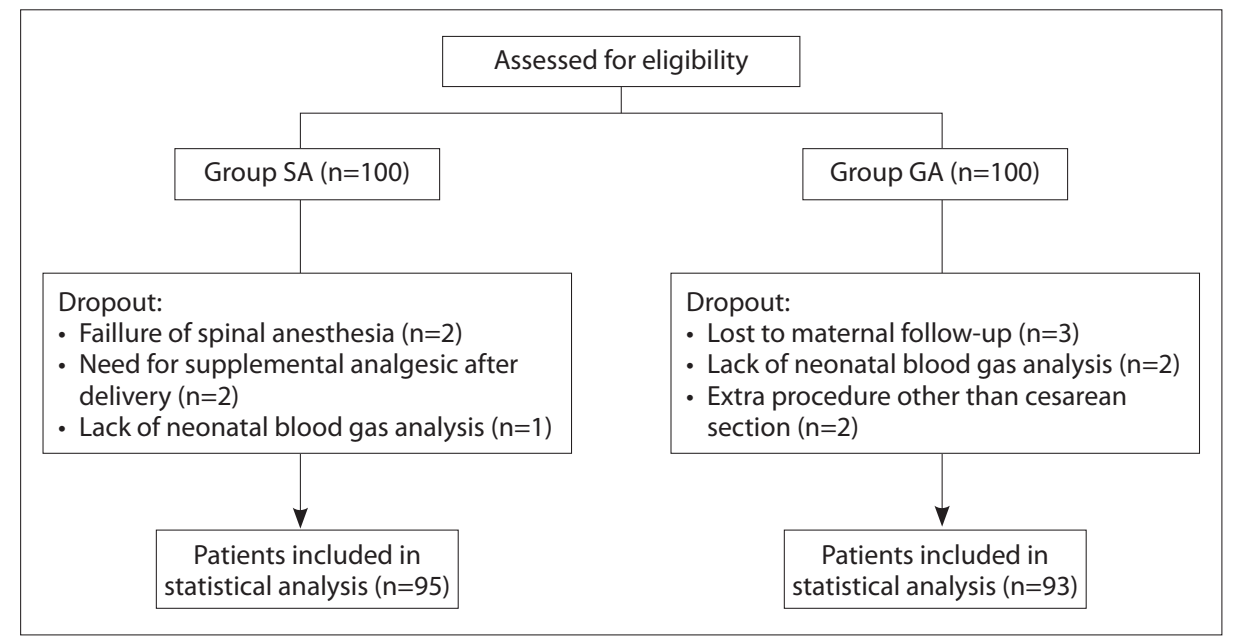

Figure 1. Study flowchart.

bilization $\left(\mathrm{T}_{\mathrm{M}}\right)$ and postoperative hospital stay were noted. Fetal gestation age, newborn height, weight, umbilical venous blood gas analysis, $1^{\text {st }}$ and $5^{\text {th }}$ min Apgar scores, presence of hypoglycemia, need for phototherapy, nutritional and ventilatory support were recorded.

\section{Statistical analysis}

In our institution, patients can be discharged at daytime between 8:00 am - 4:00 pm. Patients ready to be discharged after 4:00 pm have to wait a maximum of 16 hours. To determine a difference of 16 hours in actual hospital stay between the groups with a standard deviation of 32 hours (alpha 0.05, beta 0.1 ), we calculated a sample size of 85 patients per group. For possible dropouts, we collected the data of first 100 consented patients in each group.

Data are presented as mean $\pm \mathrm{SD}$, median [min$\max$ ] or number (percentage). Student's t-test and Mann-Whitney U-test were used for parametric and non-parametric quantitative data respectively. Chisquare or Fisher's exact test was utilized for comparing distributions of categorical data. A p value $<0.05$ was accepted as statistically significant.

\section{Results}

Patient flow through the study is shown in Figure 1. Patients' demographics, operation data and oxytocine consumption are given in Table 1. More patients in Group GA required oxytocine supplementation ( $\geq 26 \mathrm{IU})$ than those in Group SA ( 52 vs. 31 respectively, $\mathrm{p}=0.001$ ). The number of hypotensive patients, total amount of fluid given and ephedrine requirement was higher in Group SA when compared to Group GA (Table 2). Ephedrine in addition to fluids was given to two hypotensive patients in Group GA secondary to rapid oxytocine infusion because of uterine atony. The number of hypotensive episodes observed were 0[0-7] in Group SA and

Table 1. Demographics, operation data and oxytocine consumption

\begin{tabular}{lccc}
\hline & $\begin{array}{c}\text { Group SA } \\
\mathbf{n = 9 5}\end{array}$ & $\begin{array}{c}\text { Group GA } \\
\mathbf{n = 9 3}\end{array}$ & $\mathbf{p}$ \\
\hline Age (year) & $31.4 \pm 4.8$ & $31.2 \pm 5.2$ & 0.689 \\
BMI (kg/m²) & $29.83 \pm 5.2$ & $29.18 \pm 4.7$ & 0.374 \\
Gestation weeks (week) & $38.2 \pm 0.9$ & $38.3 \pm 0.9$ & 0.839 \\
Operation duration (min) & $38[19-82]$ & $35[17-85]$ & 0.149 \\
$\mathrm{~T}_{\text {S-H }}$ (min) & $4[1-11]$ & $3[1-11]$ & 0.002 \\
$\mathrm{~T}_{\text {H-U }}(\mathrm{sec})$ & $60[20-265]$ & $45[10-371]$ & 0.004 \\
Oxytocine $(\mathrm{IU})$ & $25[25-40]$ & $30[25-65]$ & 0.003 \\
\hline
\end{tabular}

BMI: Body mass index; $T_{S-H}:$ Time from skin incision to hysterotomy; $T_{H-U}:$ Time from hysterotomy to umbilical cord clamping. Data are expressed as mean \pm SD or median [min-max]. 
Table 2. Number of patients experiencing hypotension, total intraoperative fluid and ephedrine requirements

\begin{tabular}{lccc}
\hline & $\begin{array}{c}\text { Group SA } \\
(\mathbf{n = 9 5 )}\end{array}$ & $\begin{array}{c}\text { Group GA } \\
(\mathbf{n}=\mathbf{9 3})\end{array}$ & p \\
\hline Hypotensive patients (n) & $43(45.7 \%)$ & $3(3.2 \%)$ & $<0.001$ \\
Fluid (ml) & $2090 \pm 553$ & $1535 \pm 508$ & $<0.001$ \\
Ephedrine requiring patients (n) & $40(42.6 \%)$ & $2(2.2 \%)$ & $<0.001$ \\
Ephedrine (mg) & $0[0-50]$ & $0[0-10]$ & $<0.001$ \\
\hline
\end{tabular}

Data are expressed as mean \pm SD, median [min-max] or number of patients (\%).

Table 3. Intraoperative systolic blood pressure and heart rate values

\begin{tabular}{|c|c|c|c|c|c|c|}
\hline & \multicolumn{3}{|c|}{ Systolic Blood Pressure $(\mathrm{mmHg})$} & \multicolumn{3}{|c|}{ Heart Rate (beat/min) } \\
\hline & $\begin{array}{c}\text { Group SA } \\
(n=95)\end{array}$ & $\begin{array}{c}\text { Group GA } \\
(n=93)\end{array}$ & $\mathbf{p}$ & $\begin{array}{c}\text { Group SA } \\
(n=95)\end{array}$ & $\begin{array}{c}\text { Group GA } \\
(n=93)\end{array}$ & $\mathbf{p}$ \\
\hline Baseline & $135.6 \pm 15.2$ & $138.6 \pm 16.5$ & 0.671 & $107.1 \pm 15.5$ & $97.8 \pm 14.2$ & 0.158 \\
\hline $1^{\text {st }} \min$ & $121.3 \pm 16.8$ & $147.4 \pm 15.8$ & 0.001 & $100.4 \pm 17$ & $106.1 \pm 18.2$ & 0.455 \\
\hline $3^{\text {rd }} \min$ & $110.67 \pm 11$ & $132.7 \pm 9.7$ & $<0.001$ & $80.6 \pm 12.4$ & $96.4 \pm 10.5$ & 0.04 \\
\hline $6^{\text {th }} \min$ & $105.6 \pm 10.6$ & $127 \pm 12.6$ & $<0.001$ & $90.7 \pm 11.4$ & $89.4 \pm 13.8$ & 0.803 \\
\hline $9^{\text {th }} \min$ & $108.5 \pm 8.1$ & $122.1 \pm 11.6$ & 0.004 & $89.7 \pm 7.9$ & $88.9 \pm 9.9$ & 0.832 \\
\hline $12^{\text {th }} \min$ & $116.3 \pm 9.6$ & $119.6 \pm 9.3$ & 0.425 & $93.2 \pm 8.3$ & $87.6 \pm 6.4$ & 0.09 \\
\hline $15^{\text {th }} \min$ & $113.7 \pm 10.2$ & $118.8 \pm 12.2$ & 0.301 & $91.3 \pm 6.6$ & $86.1 \pm 9$ & 0.138 \\
\hline End of operation & $122.1 \pm 7.4$ & $145.9 \pm 14.4$ & $<0.001$ & $83.3 \pm 5.3$ & $97.2 \pm 9.1$ & $<0.001$ \\
\hline PACU entry & $117.8 \pm 11.5$ & $132.9 \pm 13.2$ & 0.010 & $86.8 \pm 4.4$ & $91.5 \pm 9.9$ & 0.172 \\
\hline
\end{tabular}

Data are expressed as mean \pm SD. PACU: Postoperative care unit.

0 [0-2] in Group GA $(\mathrm{p}<0.001)$. Intraoperative nausea and/or vomiting were observed in 21 patients $(22.1 \%)$ and intraoperative pruritus was seen in 37 patients $(38.9 \%)$ in Group SA. None of the parturients had postdural puncture headache or complained of intraoperative recall postoperatively.

Table 3 presents intraoperative course of SAP and heart rate values during the first 15 minutes as the shortest operation duration was 17 minutes. SAP during the first nine minutes, at the end of operation and PACU entry were significantly higher in Group GA compared to Group SA. Likewise heart rate values were significantly higher at $3^{\text {rd }}$ minutes and at the end of the operation in Group GA.

Maternal postoperative data are demonstrated at Table 4. Although $\mathrm{T}_{\text {analg }}$ was shorter in Group GA with higher pethidine consumption at PACU, no statistical difference was noted in pethidine consumptions at ward between the groups. Postoperative pain scores during the first hour were significantly higher in Group GA than Group SA and similar thereafter (Figure 2). $\mathrm{T}_{\mathrm{BF}}$ was equal in both groups. $\mathrm{T}_{\mathrm{OI}}, \mathrm{T}_{\mathrm{P}}, \mathrm{T}_{\mathrm{D}}$ was significantly shorter in Group SA. One patient in Group GA had paralytic ileus with first oral in-

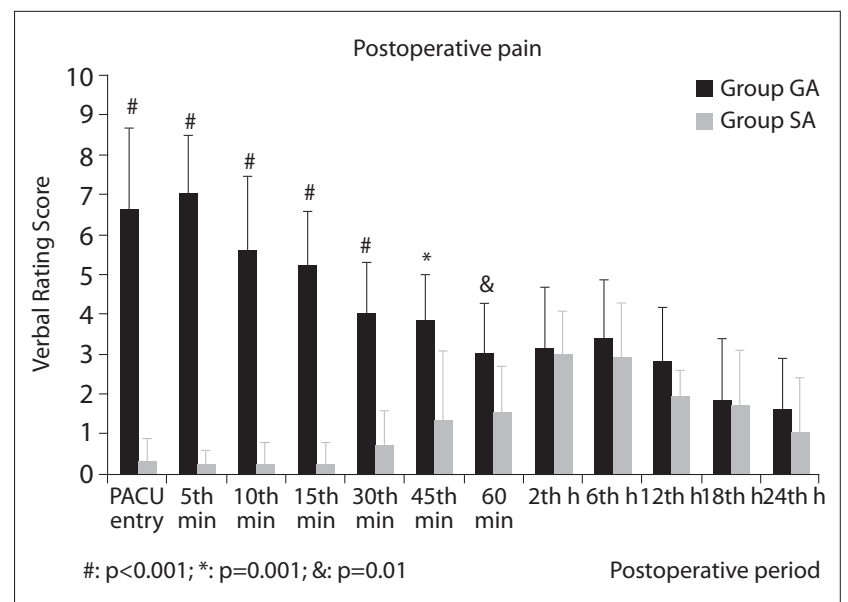

Figure 2. Postoperative pain scores (mean $\pm S D$ ). 
Table 4. Maternal postoperative data

\begin{tabular}{|c|c|c|c|}
\hline & $\begin{array}{c}\text { Group SA } \\
(n=95)\end{array}$ & $\begin{array}{c}\text { Group GA } \\
(n=93)\end{array}$ & $\mathbf{p}$ \\
\hline $\mathrm{T}_{\text {analg }}(\min )$ & $59[1-200]$ & 14 [1-69] & $<0.001$ \\
\hline Pethidine PACU (mg) & $20[0-50]$ & $30[0-60]$ & $<0.001$ \\
\hline Pethidine-PCA (mg) & $191[49-350]$ & $167.5[50-375]$ & 0.883 \\
\hline Postoperative PONV* (n) & $18(18.9 \%)$ & 15 (16.1\%) & 0.099 \\
\hline $\mathrm{T}_{\mathrm{BF}}(\min )$ & 110 [10-465] & $130[24-1374]$ & 0.256 \\
\hline $\mathrm{T}_{01}(\min )$ & 105 [10-485] & $430[180-7200]$ & $<0.001$ \\
\hline$T_{F}(h)$ & 19 [6-77] & $24[6-70]$ & 0.001 \\
\hline $\mathrm{T}_{\mathrm{D}}(\mathrm{h})$ & $24[6-51]$ & $32.5[9-96]$ & $<0.001$ \\
\hline$T_{M}(h)$ & $8[3.1-25.5]$ & $8.9[2.3-28]$ & 0.052 \\
\hline Hospital discharge (h) & 48 [21-144] & 52 [23-168] & $<0.001$ \\
\hline
\end{tabular}

take five days after surgery and she left the hospital at postoperative $7^{\text {th }}$ day. When length of stay was classified into two categories ( $<49$ hours and $\geq 49$ hours), 49 patients (55.7\%) in Group SA stayed less than 49 hours, whereas only 29 patients $(31.6 \%)$ in Group GA stayed less than 49 hours.

Neonatal data are given at Table 5. The number of neonates with $1^{\text {st }}$ min Apgar score $<7$ was three vs. zero in group GA and SA respectively $(\mathrm{p}=0.12)$. Neonates with low Apgar scores of six, six and five had $\mathrm{T}_{\mathrm{H}-\mathrm{U}}$ intervals of 330, 370 and 203 seconds respectively. All neonates had a $\mathrm{pH}$ higher than 7.2 with the exception of three neonates (two in Group SA and one in Group GA) ( $p=1)$. The first neonate in Group SA with a $\mathrm{pH}$ value of 7.13 was delivered from a mother with hypotension, and the second one with a $\mathrm{pH}$ value of 7.16 had a $\mathrm{T}_{\mathrm{H}-\mathrm{U}}$ interval of 197 seconds. First minute Apgar scores of both babies were nine. Neonate in Group GA with $\mathrm{pH}$ of 7.11 was small for gestational age with birth weight of $2370 \mathrm{~g}$. There was no statistical difference between the groups in terms of neonates with hypoglycemia or requiring nutritional support. Also no differences were observed in requirements for respiratory support and phototherapy.

Table 5. Neonatal data

\begin{tabular}{|c|c|c|c|}
\hline & $\begin{array}{c}\text { Group SA } \\
(n=95)\end{array}$ & $\begin{array}{c}\text { Group GA } \\
(n=93)\end{array}$ & $\mathbf{p}$ \\
\hline Weight (gr) & $3241 \pm 401$ & $3226 \pm 552$ & 0.84 \\
\hline Height (cm) & $48 \pm 1.8$ & $48 \pm 2$ & 0.785 \\
\hline APGAR $1^{\text {st }} \min$ & $9 \pm 0.8$ & $8.5 \pm 1.1$ & 0.001 \\
\hline APGAR $5^{\text {th }} \min$ & $9.9 \pm 0.4$ & $9.8 \pm 0.5$ & 0.105 \\
\hline $\mathrm{pH}$ & $7.344 \pm 0.051$ & $7.327 \pm 0.045$ & 0.019 \\
\hline $\mathrm{PO}_{2}$ & $28.1 \pm 8.8$ & $38.1 \pm 15$ & $<0.001$ \\
\hline $\mathrm{PCO}_{2}$ & $44 \pm 6.8$ & $47.4 \pm 7$ & 0.002 \\
\hline Respiratory support requirement (n) & $4(4.2 \%)$ & $4(4.4 \%)$ & 1 \\
\hline Hypoglycemia (n) & $4(4.2 \%)$ & $3(3.2 \%)$ & 1 \\
\hline Nutritional support (n) & $17(17.9 \%)$ & $18(19.4 \%)$ & 0.853 \\
\hline Phototherapy (n) & $2(2.1 \%)$ & $3(3.2 \%)$ & 0.681 \\
\hline
\end{tabular}

Data are expressed as mean \pm SD or number of patients (\%). 


\section{Discussion}

According to the results of this prospective study, spinal anesthesia for elective cesarean section is associated with a shorter length of postoperative hospital stay. It also enables early oral intake and recovery of gastrointestinal functions with lower oxytocine consumption, prolonged interval to first analgesic requirement. On the other hand, general anesthesia offers shorter delivery intervals with stable hemodynamics, less fluid and ephedrine requirements. Neonatal outcome was similar between the groups except $1^{\text {st }}$ min Apgar score and umbilical blood gas results.

Surgery and anesthetic technique employed has been shown to effect postoperative outcomes, specifically effecting the length of hospital stay. ${ }^{[6]}$ Rapid recovery after cesarean section should not only aim for an early return to normal daily life but also for the mother's bonding and nursing of the newborn. Spinal anesthesia has been shown to be superior to general anesthesia in previous studies in terms of maternal mortality and morbidity due to lack of airway instrumentation, avoidance of regurgitation and intraoperative awareness. ${ }^{[7-11]}$ However evidence on the effect of neuraxial anesthesia on hospital stay and discharge is missing.

General anesthesia due to its quick induction is preferred in obstetrics when urgent induction of surgery and delivery of the fetus is needed. This feature of general anesthesia is also observed in our study of elective cesarean section patients with shorter $\mathrm{T}_{\mathrm{S}-\mathrm{H}}$ and $\mathrm{T}_{\mathrm{H}-\mathrm{U}}$ intervals. One contributing factor for these short intervals in general anesthesia is the use of muscle relaxants and volatile anesthetics that can decrease abdominal muscle tone and facilitate delivery. The other is probably due to faster surgical dissection when neonatal depressive effects of general anesthetics are considered. Furthermore, when T4 sensorial level is reached in spinal anesthesia, abdominal muscle tone could still be higher than general anesthesia, as motor block routinely tested in spinal anesthesia is only for lower extremities. Studies about the effects of different anesthesia techniques on neonatal outcome do not include detailed data like skin incision-delivery or uterine incisiondelivery times. Kamat et al. studied the effect of induction-delivery and uterine-delivery on neonatal Apgar scores and found shorter induction-delivery and uterine incision-delivery intervals in general anesthesia compared to spinal anesthesia (57 vs $68 \mathrm{sec}$ respectively). ${ }^{[12]}$ On the other hand Tonni et al. compared the effects of general and neuraxial anesthesia on neonatal status and reported longer uterine incision-delivery times in general anesthesia than spinal anesthesia group (59 vs $45 \mathrm{sec}$ respectively) without statistical difference. ${ }^{[13]}$ However both authors failed to comment about these findings.

Uterine relaxing effects of volatile anesthetics is previously reported in literature. ${ }^{[14]}$ General anesthetic effect on uterine tonus is dose-dependent and reversible. In our study, although sevoflurane dose is decreased immediately after delivery with $\mathrm{N}_{2} \mathrm{O}$, midazolam and fentanyl supplementation, Group GA had increased oxytocine requirements compared to Group SA.

When hemodynamic changes are compared, the finding that hypotension is more frequent in Group $\mathrm{SA}$ is not surprising. Conventional crystalloid preloading prior to regional anesthesia is no longer recommended due to lack of efficacy. ${ }^{[15,16]}$ As the need for intravascular volume expansion starts with sympathetic blockade of spinal anesthesia, coloading is to be more beneficial to decrease vasoconstrictor requirement. ${ }^{[17]}$ Parturients in this study were cohydrated with the start of spinal anesthesia as reflected in increased fluid consumption in Group SA. However, we still encountered hypotension which was treated with ephedrine boli. Hypotension can lead to maternal discomfort due to nausea, vomiting, light headedness and most important placental hypoperfusion and fetal compromise. Ephedrine can also lead to neonatal acidosis. ${ }^{[18]}$ Yet, our treatment of hypotension seems to be effective both for the parturient and newborn as reflected by similar neonatal Apgar scores and umbilical blood $\mathrm{pH}$ values in both groups.

The time to first postoperative analgesic requirement in Group SA was longer as sensorial block duration overextends surgical operation time. This also led to decreased pethidine consumption at PACU. However after the sensorial block recovery of the single-shot spinal anesthesia, patients required simi- 
lar analgesic amounts as reflected by PCA-pethidine delivery. To our knowledge there is no study in the literature comparing spinal and general anesthesia in terms of first analgesic requirement time. Kessous et al., who described meperidine as a rescue in severe pain, reported higher number of meperidine requiring patients in the first $24 \mathrm{~h}$ following general anesthesia compared to spinal anesthesia for cesarean section. ${ }^{[19]}$

One interesting result is that there was no difference between the groups in terms of breastfeeding. This may be due to the time needed by the neonatology team to examine the newborn as well as staff inadequacies resulting in a delayed meeting of the baby with the mother. Sener et al. compared epidural with general anesthesia for cesarean section and reported similar first breast feeding time for epidural anesthesia whereas prolonged duration for first breast feeding following general anesthesia (107.4 vs 228.07 min respectively). ${ }^{[20]}$

One of the most important findings of this study is the early recovery of gastrointestinal functions following spinal anesthesia. One important reason for early return of flatulence and defecation in Group SA is the sympathetic blockade. Sympathetic flow is the dominating inhibitory control for gastrointestinal system. When sympathetic flow is blocked and unopposed parasympathetic stimulation remains, motility in stomach, small bowel and proximal colon is increased. ${ }^{[21,22]}$ Another reason may be late oral intake observed in Group GA. This late intake may be due to residual sedative effects of general anesthetics. There is no study comparing the effects of different anesthesia techniques for cesarean section on gastrointestinal function. However a recent meta-analysis of studies focus on early oral intake which may promote gastrointestinal recovery. ${ }^{[23]}$ Ambulation, postoperative opioid consumption and PONV may further affect bowel recovery; however TM interval, pethidine consumption and PONV incidence were similar between the groups in this study.

Primary outcome of this study, length of postoperative hospital stay, was shorter in Group SA when compared to Group GA. There are only two studies from the same authors looking at the effect of anesthesia type on hospital stay. ${ }^{[24,25]}$ Our finding are similar to Fassoulaki et al. who reported postoperative hospital stay between years 2002-2005. They showed a progressive decrease during this period of time and especially after neuraxial (combined spinal-epidural or epidural) anesthesia when compared to general anesthesia. ${ }^{[24]}$ However, compared to our results (median 2 days) they reported a longer hospital stay (median 4 days) following neuraxial anesthesia, even in the final year of the study period. This may depend on the late oral intake allowed only after the removal of urinary and epidural catheters. It may also be attributed to the differences in institutional obstetric team policy. The large volume of obstetric patients in our institution accelerates bed turnover. According our obstetric team, uncomplicated patients following cesarean section with recovered bowel function, tolerance of oral intake, lack of micturition problems and ability to take care of the baby can be discharged.

In terms of neonatal outcome, the lower $1^{\text {st }}$ min Apgar scores in Group GA can be the result of neonatal depression by general anesthesia. ${ }^{[1]}$ Also when neonates with Apgar scores $<7$ are examined, three neonates in Group GA had corresponding $\mathrm{T}_{\mathrm{H}-\mathrm{U}}$ intervals $>180$ seconds which may be responsible for this result. ${ }^{[26]}$ However, the small difference in $1^{\text {st }}$ min Apgar scores between the groups is clinically insignificant as the $5^{\text {th }}$ minute scores are similar. Kavak et al. ${ }^{[27]}$ reported similar $1^{\text {st }}$ and $5^{\text {th }}$ minute Apgar scores, whereas Tonni et al. ${ }^{[13]}$ and Mancuso et al. ${ }^{[4]}$ observed more depressed newborns in general compared to spinal anesthesia. Neonates of mechanically ventilated mothers in Group GA had also higher $\mathrm{PCO}_{2}$ values. Pregnant patients have physiologically higher respiratory frequencies during spontaneous breathing. We ventilated our patients receiving general anesthesia to keep ETCO $\mathrm{E}_{2}$ between $32-35 \mathrm{mmHg}$ and they had possibly higher $\mathrm{PCO}_{2}$ levels compared to spontaneous breathing patients under spinal anesthesia. As the removal of neonatal $\mathrm{PCO}_{2}$ occurs via maternal lungs, these neonates had also slightly higher $\mathrm{CO}_{2}$ values. The lower $\mathrm{pH}$ values of neonates in Group GA are the result of slightly higher $\mathrm{PCO}_{2}$. Hodgson and Wauchob also reported slightly lower $\mathrm{pH}$ values of newborns with $\mathrm{T}_{\mathrm{H}-\mathrm{U}}$ less than three minutes in general anesthesia. ${ }^{[28]}$ The higher $\mathrm{PO}_{2}$ values of the neonates in Group GA 
is expected due to positive pressure ventilation of the mothers with $100 \% \mathrm{O}_{2}$ until delivery similar to Ochiai et al. ${ }^{[29]}$ Early outcomes of neonates in terms of respiratory and nutritional support, incidence of hypoglycemia and need for phototherapy were similar between the groups. Tonni et al. found similar incidence of hypoglycemia in spinal and general anesthesia groups too. ${ }^{[13]}$ Ozcakir et al. observed no differences between epidural and general anesthesia in terms of phototherapy needs. ${ }^{[30]}$

The lack of other neuraxial techniques can be seen as a limitation of the study. But we aimed to compare the two routine anesthesia methods, namely general and spinal anesthesia of our daily practice. We also think that spinal anesthesia was more comparable with general anesthesia rather than a neuraxial technique with catheter, for it was applied as single shot and did not include long-acting opioids.

The use of high inspired oxygen concentration until delivery can be seen as a drawback of the study. We administered $100 \%$ oxygen to increase fetal oxygenation during this period as hysterotomy causes an interruption in oxygen delivery to the fetus. This may help to overcome a decrease of fetal oxygen reserve in unexpected prolonged hysterotomy to delivery periods. Pregnancy leads to a decrease in minimum alveolar concentration of volatile anesthetics up to $40 \%$ (60\% MAC of sevoflurane $\approx 1.2 \%) .{ }^{[31,32]}$ As $\mathrm{N}_{2} \mathrm{O}$ is omitted we used a higher inspiratory sevoflurane fraction to avoid intraoperative awareness. The reported incidence of awareness in cesarean section is $0.1-0.3 \%$, therefore this study is underpowered to comment about awareness. However we did not encounter recall in the postoperative period.

One other limitation is that umbilical venous instead of arterial blood gas analysis was obtained. Although umbilical venous sampling is easier, arterial samples would better reflect fetal acid-base status.

Fast-tracking in elective cesarean section is not well studied in terms of anesthetic technique as most western countries employ regional anesthesia. ${ }^{[33]}$ However this is not the case in Turkey, where a recent survey of obstetric anesthesia practice has shown relatively low ratio of regional anesthesia (36.1\%) for cesarean section when compared with western countries. ${ }^{[34]}$ Other than unavailability of obstetric anesthetic care, patients' choice and obstetric team preference may play a role in these low numbers. Demonstrating the beneficial effect of spinal anesthesia on hospital stay can further convince both the parturient to choose and the obstetric team to promote neuraxial anesthesia.

In conclusion spinal anesthesia when compared to general anesthesia for elective cesarean section allows faster discharge from the hospital. Fast recovery and return of the mother to the family offers social benefits as well as quick turnover of hospital beds in heavily occupied clinics.

\section{References}

1. Wong CA. General anesthesia is unacceptable for elective cesarean section. Int J Obstet Anesth 2010;19(2):209-12.

2. Kan RK, Lew E, Yeo SW, Thomas E. General anesthesia for cesarean section in a Singapore maternity hospital: a retrospective survey. Int J Obstet Anesth 2004;13(4):221-6.

3. Algert CS, Bowen JR, Giles WB, Knoblanche GE, Lain SJ, Roberts CL. Regional block versus general anaesthesia for caesarean section and neonatal outcomes: a population-based study. BMC Med 2009;7:20. [CrossRef]

4. Mancuso A, De Vivo A, Giacobbe A, Priola V, Maggio Savasta L, Guzzo M, et al. General versus spinal anaesthesia for elective caesarean sections: effects on neonatal short-term outcome. A prospective randomised study. J Matern Fetal Neonatal Med 2010;23(10):1114-8. [CrossRef]

5. Afolabi BB, Lesi FEA, Merah NA. Regional versus general anaesthesia for caesarean section. Cochrane Database Syst Rev 2006;4:CD004350.

6. Carli F, Baldini G. Fast-track surgery: it is time for the anesthesiologist to get involved! Minerva Anestesiol 2011;77(2):22730.

7. Hawkins JL, Chang J, Palmer SK, Gibbs CP, Callaghan WM. Anesthesia-related maternal mortality in the United States: 1979-2002. Obstet Gynecol 2011;117(1):69-74. [CrossRef]

8. Ross BK. ASA closed claims in obstetrics: lessons learned. Anesthesiol Clin North America 2003;21(1):183-97. [CrossRef]

9. Cooper GM, McClure JH. Maternal deaths from anaesthesia. An extract from Why Mothers Die 2000-2002, the Confidential Enquiries into Maternal Deaths in the United Kingdom: Chapter 9: Anaesthesia. Br J Anaesth 2005;94(4):417-23.

10. Paech MJ, Scott KL, Clavisi O, Chua S, McDonnell N; ANZCA Trials Group. A prospective study of awareness and recall associated with general anaesthesia for caesarean section. Int J Obstet Anesth 2008;17(4):298-303. [CrossRef]

11. Bowring J, Fraser N, Vause $\mathrm{S}$, Heazell AE. Is regional anaesthesia better than general anaesthesia for caesarean section? J Obstet Gynaecol 2006;26(5):433-4. [CrossRef]

12. Kamat SK, Shah MV, Chaudhary LS, Pandya S, Bhatt MM. Effect of induction-delivery and uterine-delivery on apgar scoring of the newborn. J Postgrad Med 1991;37(3):125-7.

13. Tonni G, Ferrari B, De Felice C, Ventura A. Fetal acid-base and neonatal status after general and neuraxial anesthe- 
sia for elective cesarean section. Int J Gynaecol Obstet 2007;97(2):143-6. [CrossRef]

14. Munson ES, Embro WJ. Enflurane, isoflurane, and halothane and isolated human uterine muscle. Anesthesiology 1977;46(1):11-4. [CrossRef]

15. Dyer RA, Farina Z, Joubert IA, Du Toit P, Meyer M, Torr G, et al. Crystalloid preload versus rapid crystalloid administration after induction of spinal anaesthesia (coload) for elective caesarean section. Anaesth Intensive Care 2004;32(3):351-7.

16. Mercier FJ. Fluid loading for cesarean delivery under spinal anesthesia: have we studied all the options? Anesth Analg 2011;113(4):677-80. [CrossRef]

17. Ngan Kee WD. Prevention of maternal hypotension after regional anaesthesia for caesarean section. Curr Opin Anaesthesiol 2010;23(3):304-9. [CrossRef]

18. Reidy J, Douglas J. Vasopressors in obstetrics. Anesthesiol Clin 2008;26(1):75-88, vi-vii. [CrossRef]

19. Kessous R, Weintraub AY, Wiznitzer A, Zlotnik A, Pariente G, Polachek $\mathrm{H}$, et al. Spinal versus general anesthesia in cesarean sections: the effects on postoperative pain perception. Arch Gynecol Obstet 2012;286(1):75-9. [CrossRef]

20. Sener EB, Guldogus F, Karakaya D, Baris S, Kocamanoglu S, Tur A. Comparison of neonatal effects of epidural and general anesthesia for cesarean section. Gynecol Obstet Invest 2003;55(1):41-5. [CrossRef]

21. Steinbrook RA. Epidural anesthesia and gastrointestinal motility. Anesth Analg 1998;86(4):837-44. [CrossRef]

22. Carpenter RL. Gastrointestinal benefits of regional anesthesia/analgesia. Reg Anesth 1996;21(6 Suppl):13-7.

23. Mangesi L, Hofmeyr GJ. Early compared with delayed oral fluids and food after caesarean section. Cochrane Database Syst Rev 2002;(3):CD003516.

24. Fassoulaki A, Petropoulos G, Staikou C, Siafaka I, Sarantopoulos $C$. General versus neuraxial anaesthesia for caesarean section: impact on the duration of hospital stay. J Obstet
Gynaecol 2009;29(1):25-30. [CrossRef]

25. Fassoulaki A, Staikou C, Melemeni A, Kottis G, Petropoulos G. Anaesthesia preference, neuraxial vs general, and outcome after caesarean section. J Obstet Gynaecol 2010;30(8):81821. [CrossRef]

26. Datta S, Ostheimer GW, Weiss JB, Brown WU Jr, Alper MH. Neonatal effect of prolonged anesthetic induction for cesarean section. Obstet Gynecol 1981;58(3):331-5.

27. Kavak ZN, Başgül A, Ceyhan N. Short-term outcome of newborn infants: spinal versus general anesthesia for elective cesarean section. A prospective randomized study. Eur J Obstet Gynecol Reprod Biol 2001;100(1):50-4. [CrossRef]

28. Hodgson CA, Wauchob TD. A comparison of spinal and general anaesthesia for elective caesarean section: effect on neonatal condition at birth. Int J Obstet Anesth 1994;3(1):2530. [CrossRef]

29. Ochiai N, Tashiro C, Okutani R, Murakawa K, Kinouchi K, Kitamura S. Improved oxygen delivery to the fetus during cesarean section under sevoflurane anesthesia with 100\% oxygen. J Anesth 1999;13(2):65-70. [CrossRef]

30. Ozcakir HT, Lacin S, Baytur YB, Lüleci N, Inceboz US. Different anesthesiologic strategies have no effect on neonatal jaundice. Arch Gynecol Obstet 2004;270(3):179-81. [CrossRef]

31. Palahniuk RJ, Shnider SM, Eger El 2nd. Pregnancy decreases the requirement for inhaled anesthetic agents. Anesthesiology 1974;41(1):82-3. [CrossRef]

32. Chan MT, Mainland P, Gin T. Minimum alveolar concentration of halothane and enflurane are decreased in early pregnancy. Anesthesiology 1996;85(4):782-6. [CrossRef]

33. Şahin Ş, Owen M. Türkiye'de ve Dünyada Obstetrik Analjezi ve Anestezi. Türk Anest Rean Cem Mecmuası 2002;30:52-9.

34. Töre G, Gurbet A, Şahin Ş, Türker G, Yavaşcaoğlu B, Korkmaz S. Türkiye'de Obstetrik Anestezi Uygulamalarındaki Değişimin Değerlendirilmesi. Türk Anest Rean Cem Mecmuası 2009;37:86-95. 